\title{
THE BRITISH CARDIAC SOCIETY AND THE CARDIAC CLUB: 1922-1961
}

BY

\section{MAURICE CAMPBELL*}

At this, the 26th annual meeting of the British Cardiac Society, the Council has decided that there should be some recognition of the 25 years of the Society and of the preceding 15 years of the Cardiac Club, and has honoured me with an invitation to deliver a commemorative address. The task could be approached in several ways. It would be interesting to review the wonderful advances of cardiology in these 40 years-advances that have developed in new directions as soon as one line has come to a temporary halt-and to record the part played by members of the Society.

When I mention some of these advances-(1) the importance of precise ætiology in prognosis and treatment instead of the use of vague terms like myocardial degeneration (Cabot and White, 1921); (2) the clinical recognition of coronary thrombosis by Herrick (1912-22), of its cardiographic diagnosis by Pardee (1920) and by Parkinson and Bedford (1928); (3) the use of chest leads and the greater understanding of electrocardiography from the work of Frank Wilson and his school (1930-36), and the introduction of vectorcardiography; (4) the more effective treatment of congestive heart failure by the wider use of salt restriction following the work of Widal in France and later of Allen in America, and by the introduction of better mercurial diuretics by Saxl of Vienna (1920) and of digoxin (1930); (5) the separation of right-sided and left-sided heart failure, emphasized by Lian in Paris and by Bedford; (6) the recognition of the complete reversibility of heart failure when the cause is known, as in thyrotoxicosis and myxœdema (1924); (7) the use of radiology and radioscopy, helped forward so much by Parkinson; (8) the use of quinidine in the treatment of the arrhythmias (1921); (9) the introduction of anticoagulants; (10) the discovery of penicillin and its value in bacterial endocarditis (1945); and in more recent times (11) the greater understanding of congenital heart disease, helped by cardiac catheterization (Cournand, Dexter, and McMichael and SharpeySchafer) and by angiocardiography (Castellanos, 1935-38; and Robb and Steinberg, 1938); and (12) the surgical treatment of so many congenital heat conditions culminating in the direct operations on the heart (Brock, 1948) and the surgical treatment of mitral stenosis (1948-50)-when I mention all these advances, you will see that it would take me too long. These have become so much a part of our lives that it is easy for the younger among us to forget how recent is their introduction. A physician of 1922 who had been interested in diseases of the heart would find himself in 1962 in a new world of practice and research that he did not understand.

It seems more appropriate on a domestic occasion such as this to speak of our own history and growth. Social and economic developments, wars, and politics are sometimes regarded as the backbone of history, but to me the influence of great men and women on the circumstances of their time has always been of more interest, and I think this is an occasion when in the words of Ecclesiasticus we should "now praise famous men and our fathers that begat us."

JAMES MACKENZIE

James Mackenzie (1853-1925) was chosen as the only Honorary Member of the Cardiac Club (Fig. 1). He had left the cardiac department of the London Hospital four years before the Club

* Parts of this paper were given at the Annual Meeting at Birmingham, May 3, 1962 . We hope that readers who are not members of the Society will excuse this domestic chronicle. 
Fig. 1.-Sir James Mackenzie, F.R.S., the only Honorary Member of the Cardiac Club. 
was formed to become the Director of the Institute of Clinical Research at St. Andrew's, and so had no direct part in its formation. But he had written to Cushny years before to suggest it and must be regarded as its inspiration, for all the original members had been influenced by him and most of them had visited him or worked with him.

Cowan (1939) wrote that the Cardiac Club was conceived in Burnley but the period of gestation was a long one. It would be equally true to say that modern cardiology was conceived in Burnley. Though one might argue about the exact date, the publication of Mackenzie's book The Study of the Pulse in 1902 would be my choice, for this really solved the problem of the arrhythmias; though it was not till 1909 that Lewis, an original member of the Club, and Wenckebach, an Honorary Member of the Society, related the gross irregularity of the pulse with auricular fibrillation. You all know this great book, but do you all remember when looking at it that the graphic records on which it was based were recorded on a smoked drum (before Mackenzie had invented his more practicable ink polygraph) and that he had to carry this on his bicycle as he went about his daily rounds?

This is not the place to record Mackenzie's life and work for in 1953, the centenary of his birth, Parkinson spoke of his memories of Mackenzie at the London Hospital and before (B.H.J., 16, 125; see also Lancet, 1955, 1, 1013), and you should soon be able to read about it in a new life that is in preparation by Professor A. Mair of the University of St. Andrews. Mackenzie made great discoveries despite all difficulties, but even more important he influenced the whole approach to cardiology and to the care and treatment of patients with heart disease. The main reason for his success was the combination of an insatiable curiosity about how the heart worked and failed, with a love of his patients that made him hate to see them unable to do as much as possible of what they wanted to do. He was a great man who has done more than anyone else in the last eighty years for cardiology and for patients with heart disease. Without him the Cardiac Society of today would be very different.

\section{The Cardiac Club (1922-37)}

During the 1914-18 war, V.D.H. (valvular disease of the heart) and D.A.H. (disordered action of the heart) were two of the most common diagnoses and some of us remember how often they were wrong. In April 1920 the Ministry of Pensions appointed consultants in cardiology to assist the Regional Directors in the assessment and treatment of cardiac patients. These consultants met together from time to time in London and discussed not only administrative problems but also subjects of cardiological interest-the influence of war service on bacterial endocarditis, malaria and the myocardium, quinidine in auricular fibrillation, etc. They found these meetings useful and thought it would be a good thing to form a club to meet more regularly to talk over cardiological subjects in general and electrocardiograms in particular, for by now they were all taking them and finding new problems. The start of the Cardiac Club was a co-operative effort with many ready helpers, but perhaps the names of Hume and of Cowan, who was chiefly responsible for drawing up its simple rules and regulations, should be specially remembered.

This is the story as it is generally given but among the documents is a typed list of the 15 original members, showing their rank in the Army List of November 1918. All of them had served in the army in the 1914-18 war except Lewis who was investigating soldiers with disordered action of the heart at Hampstead and Colchester. The list shows that Cowan and Hume had been the only two full colonels, Griffith and Hay had been lt. colonels, and most of the others majors. Had they seen enough of each other while in uniform still to feel the authority of the senior rank of these two in civilian life?

Be that as it may, the first document in the minutes of the Club is a letter dated February 21, 1922 from Hume to Cowan, suggesting that Cowan should call together a meeting of people interested in cardiography before the next meeting of the Association of Physicians. This meeting was held at Oxford on April 22, 1922, with A. G. Gibson in the chair, and decided to form the Cardiac Club which should meet once a year without encroaching on the functions of the Association. There 


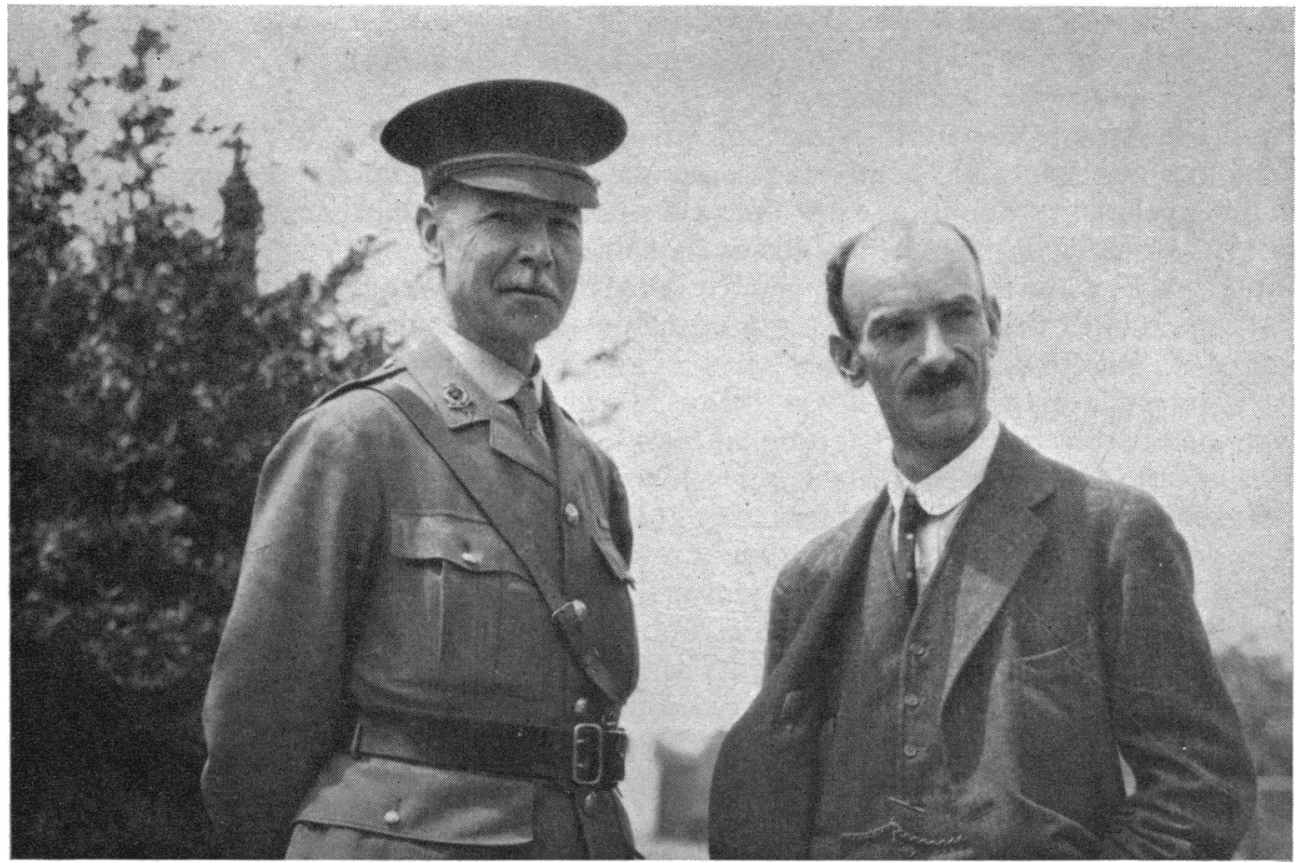

FIG. 2.-Wardrop Griffith, the doyen of the Cardiac Club, with Thomas Lewis.

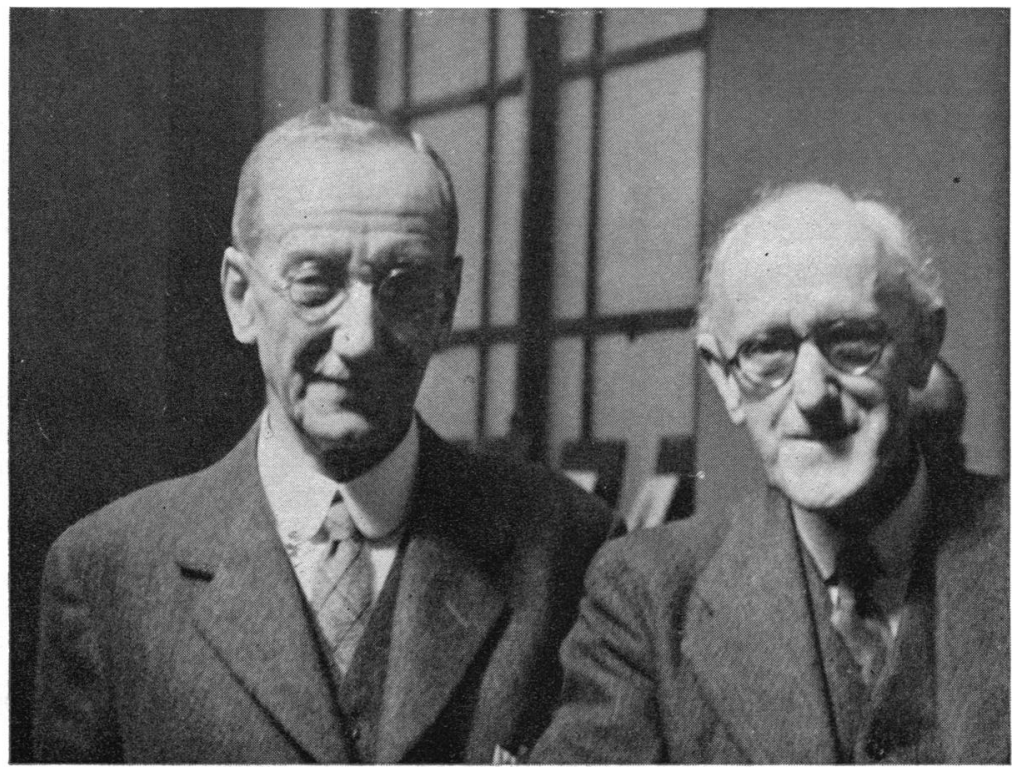

Fig. 3.-John Cowan, the first secretary of the Cardiac Club, with H. J. Starling. 
were 15 original members and I can see them all clearly before me as I speak to you. I will say nothing about Tom Cotton and John Parkinson for they fortunately are still with us.

Wardrop Griffith (1861-1947: Fig. 2) was admirably fitted to be the doyen of the Club, both in appearance and character: last year was the centenary of his birth. Impressive, tall, and goodlooking, the essence of kindness though a stern disciplinarian, Professor of Anatomy when 26 (1887-1910), Physician to the General Infirmary at Leeds (1892-1925), and Professor of Medicine (1910-1925), he was meticulous in all his duties, as befitted an Aberdonian: it was said that he personally supervised the laying of every stone of the new Leeds Medical School. He was a lucid demonstrator, as he showed at the 1934 meeting with many difficult congenital hearts.

John Cowan (1870-1948: Fig. 3) was the first secretary of the Club. In spite of his natural reserve and a certain shyness, he became a trusted friend of us all. Though he was elderly when I became a member, he never failed to give me, as secretary, valuable help in any problem that was put to him. His father and grandfather before him had been physicians to the Glasgow Royal Infirmary. On his appointment to the staff he did much to modernize the medical work in the wards, and he wrote the best text book on cardiology of the time (later editions with Ritchie). An indefatigable worker, he retained his youthful enthusiasm till the end. We in the Society owe much to him.

Thomas Horder (1871-1955) - Lord Horder after 1933-was a general physician who was gladly accepted in the Club for his early work on baterial endocarditis and his wide experience of heart disease. His meticulous care for detail and his gift for noting the essential points and disregarding the less significant made him one of the great clinicians of his day. He was medical adviser to many famous people including three Kings and three Prime Ministers. His wide interests and his vivacious and active mind, with his slightly harsh voice, always added something to our meetings.

J. G. Emanual (1871-1958) spent most of his life at Birmingham, except for resident posts in several London hospitals, a voyage to Australia as medical officer in a sailing ship in 1897-98, and service in France in 1914-18. For many years he was the only physician in the Midlands who understood the mysteries of the polygraph and electrocardiograph, and he wrote about the cardiac arrhythmias. Kind and with the grace of humility, he found nothing too much trouble for his patients, students, and hospitals. His spare time was spent climbing, in North Wales and in the Alps. He and Hay were the first members whose sons have followed them as members of the Cardiac Society.

John Hay (1873-1959: Fig. 7) was an influential figure in the medical life of Liverpool for fifty years. One of the earliest disciples of Mackenzie, he was the first to describe the onset of heart block without preceding change in the A-V interval. He was a great clinician who gave confidence and courage to his patients, and was an outstanding teacher of medicine. Though his last talk to the Society was in 1941 on coronary thrombosis, his felicity of speech and his wealth of reminiscence kept him in demand as an after dinner speaker, and he was always the centre of a group who were anxious to talk to him and to hear what he had to say. He was a profound lover of beautyin music, in painting, in flowers, and in life.

W. T. Ritchie (1873-1945) of Edinburgh was a distinguished physician and looked the part. He discovered clinical auricular flutter, and had been a pathologist in his early days. He was our treasurer for the first ten years. He was perhaps less easy to know than most of the others, but the younger men who got to know him became his devoted followers.

H. J. Starling (1873-1950: Fig. 3) of Norwich was a character and a fluent talker who loved an argument. He was a brother of the great physiologist and an authority on subacute bacterial endocarditis, especially the form that was so prevalent in soldiers without previous heart disease in the 1914-18 war. His long thin face lent itself to caricature as was shown in the drawing by Strube (B.H.J., 13, 261), the well-known cartoonist, who was a patient in the Colchester Heart Hospital.

J. E. MacIlwaine (1874-1930) of Belfast was tall and had a deep attractive voice and the complexion of a country squire. He had been an Irish Rugby international. He had been given to rather transient enthusiasms but the electrocardiograph retained its hold on his imagination. $\mathrm{He}$ should have lived into the present age for he had studied engineering and naval architecture before 


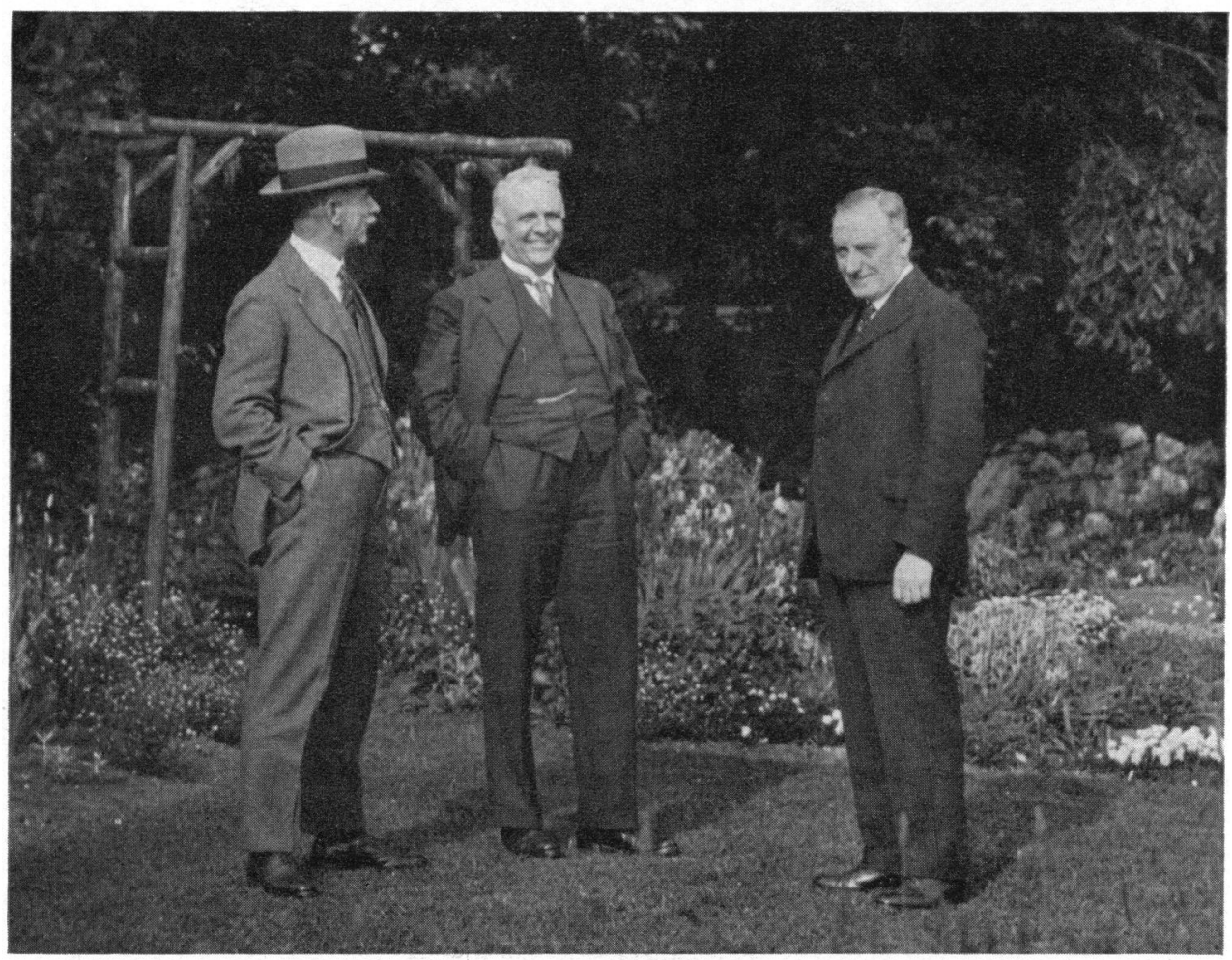

Fig. 4.-A. G. Gibson (the second secretary of the Club), on the right, Carey Coombs, and Lewis in John Hay's garden at Aigburth, about 1928.

medicine, but he lost his sight and died in his fifties. He was a generous and kindly friend and a great Queensman.

A. G. Gibson (1875-1950: Fig. 4), a short sturdy figure, was much loved by generations of Oxford medical students. He was a great pathologist with a wide knowledge of coronary disease and a good physician, the first to recognize the third heart sound. He wrote also about The Radcliffe Infirmary and a charming book on The Physician's Art.

Carey Coombs (1879-1932: Fig. 4) was one of the great physicians that Bristol has produced. His Lumleian Lecture (1930) on Cardiovascular Syphilis is still of value. His book Rheumatic Heart Disease, published in 1924, is rightly regarded as a classic for a disease in which he had been interested since working under Poynton at St. Mary's. He was built in a large mould, physically and mentally. It was always a pleasure to meet him or to listen to him speaking, for he was a man of singular friendliness, who was gifted with style and clarity in both speech and writing.

W. E. Hume (1879-1960: Fig. 5) - Sir William after 1952-was appointed to the Staff of the Royal Victoria Infirmary Newcastle, when he was 28 and quickly became one of the best-known physicians in the North. He wrote on the cardiac arrhythmias and, after the 1914-18 war in which he gave distinguished service, on spirochætal jaundice, encephalitis lethargica, and war nephritis. He was able to act as our Chairman at Newcastle in 1953, though sadly crippled by arthritis for his last ten years. He was a keen fisherman. In his Harveian Oration in 1943 on The Physician in War -in Harvey's Time and After, his sense of history helped him in tracing Harvey's journeys to the North with Charles I.

Thomas Lewis (1881-1945) was one of our most outstanding scientists. You all know his work on conduction in the heart and later on the responses of the small blood vessels-work that led to 


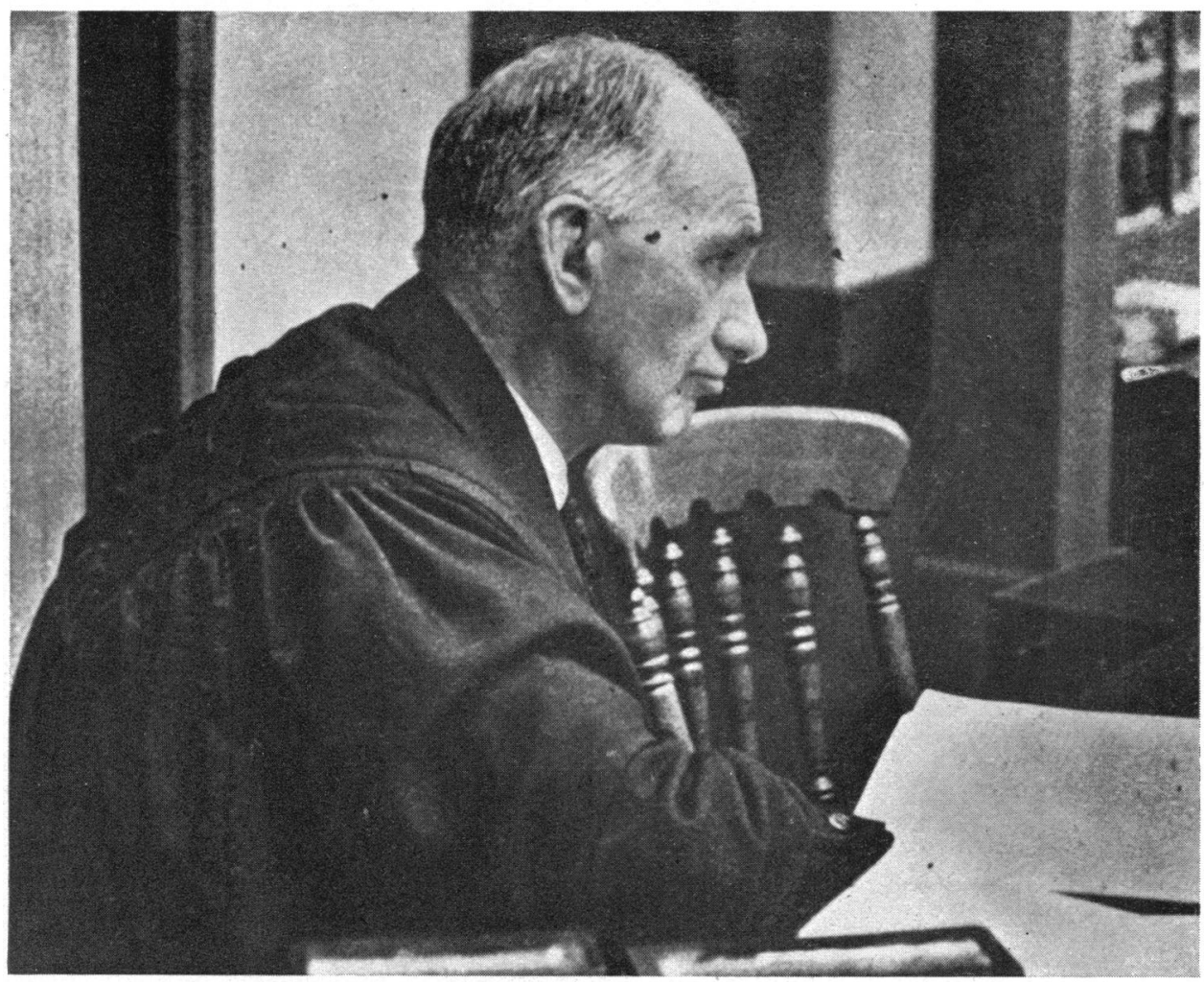

FIG. 5.-W. E. Hume, examining in medicine.

fundamental advances. He was a great editor and a good writer with a natural style, though he always emphasized the care and effort that must be put into all writing to make it clear and precise. He gave us help and encouragement in starting the British Heart Journal and wrote a preface for the first number. His spare time was devoted to fishing and ornithology. His active enquiring mind is well expressed in the painting by Evan Walters (Fig. 6).

K. D. Wilkinson (1886-1951) of Birmingham, with his perky figure and broad expanse of waistcoat, with his fund of stories told in any dialect, with his Leica or his cine-camera that took many films of our meetings, seemed to belong to a later generation. He was an authority on diphtheritic myocarditis, on rheumatic heart disease, and on William Withering, about whom he wrote an excellent book.

They were-great men and I was proud to be associated with them and to call them my friends. Often they had taught pathology or physiology or anatomy in their early years, but this did not prevent them becoming physicians of distinction. Most of them were born in the seventies, so they were old enough to have reached some eminence in those leisured and care-free years before the 1914-18 war. Did this environment help to produce outstanding characters with wide interests? Or is this merely an impression of an observer who was young at the time?

The original members of the Club were gradually joined by others-by Bramwell and Fraser in 1923, Drury and Herapath* in 1924, Kennedy* and Patterson* in 1925, Allan* and Cassidy* in 1926, Boyd Campbell and Stott* in 1927, Wallace Jones* and Bedford in 1928, Poulton* in 1930, Maurice Campbell in 1931, Grant and Gilchrist in 1933, Abrahamson* and Curtis Bain in 1934, and

* Members who have died: see list of memoirs at end. 


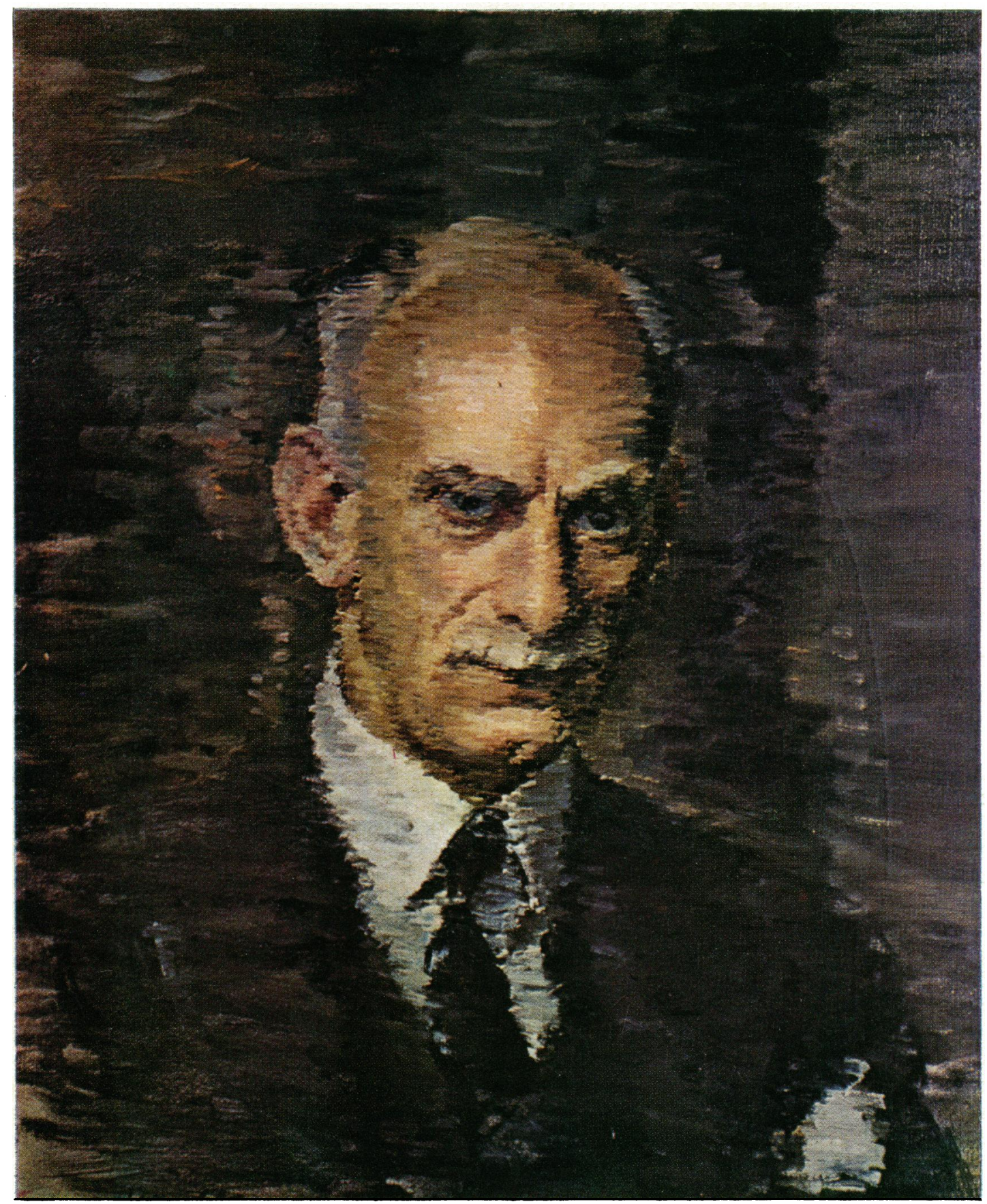

Fig. 6.-Sir Thomas Lewis, F.R.S., from a painting by Evan Walters. By courtesy of the National Museum of Wales 
Bruce Perry in 1936. Two new members was the largest number elected in any one year and sometimes there was only one and even none. Unfortunately nine of these other members have died and six of them are hitherto without a memoir in our journal.

Leonard Abrahamson (1897-1961) was a Gælic and Hebrew scholar before he took up medicine. He wrote an early account of thrombo-phlebitis migrans but was better known for his work as a consultant in cardiology and general medicine. He became President of the Irish College of Physicians in 1949 . He was a leader of Irish Jewry but was loved by a much wider circle of friends and patients.

George A. Allan (1876-1950) was in business for a time before starting medicine. He carried on a busy general practice as well as his duties at the Western Infirmary, Glasgow, with his growing interest in cardiology, until he was 44 . His gentle kindly manner concealed a strong character and he became a successful consultant, a most stimulating teacher, and a joint editor of the Glasgow Medical Journal. He was our Chairman in 1933.

Henry Wallace Jones (1888-1958) had a distinguished career as physician and cardiologist at Liverpool, and proved himself an able clinical teacher at the Royal Infirmary. His publications were not numerous but were firmly based on physiological training and extensive clinical experience. He had a wide circle of friends but his tall slim figure was not well known to our younger members as he retired from his hospital early and went to live in South Africa.

A. M. Kennedy (1885-1960) made his name at Glasgow by his work on the histological changes in the conducting system of the heart. He became an outstanding clinician and was chosen as the first professor of medicine at Cardiff where he had to build up a new department in face of many difficulties and much opposition. He never allowed himself to be overwhelmed by these and devoted himself to his students, broadening his interests with some loss to cardiology. All now agree that he performed a great service for the Welsh National School of Medicine. He was a painter in water colours and had a good collection of these and of prints.

S. W. Patterson (1886-1960) was an Australian who had been in general practice. He came to London to work with Starling, and helped him with some of his most fundamental physiological work on the heart (Patterson and Starling, 1914a and $b$ ). He married Starling's daughter. Returning to medicine, he worked for 30 years at a private nursing home with Sir Edmund Spriggs at Ruthin Castle, North Wales, where he maintained the highest scientific standards. Though much occupied with general medicine, he remained a learned cardiologist and a constant friend of the Society.

E. P. Poulton (1883-1939). I have written about him fully in the Guy's Hospital Reports (89, 251). No one could have wished for a more loyal friend, with a child-like enthusiasm for science. He had worked in Germany and had a wide knowledge of biochemistry, which he turned to good account in his work on diabetes, being one of the first to use insulin at a time when he himself extracted it from the pancreas. He was also an enthusiast for oxygen therapy, but in clinical medicine he was at times unpredictable. He must have known less about the electrocardiogram and more about the physiological changes in congenital heart disease than any other member.

At most meetings of the Club, there were two set subjects with speakers chosen beforehand, as well as even more informal discussions of the short communications and of cases. Sometimes the set subject was based on the experience of all the members during the year. This was so when Hay spoke about quinidine in 1923 and when Gibson spoke about anæmic, or as we should now say ischæmic, necrosis of the heart in 1925 . Only once in the 15 years of the Club did congenital heart disease have more than a passing mention. As well as Griffith's demonstration in 1934, Parkinson and Bedford emphasized the large pulmonary arteries of atrial septal defect, the clinical features of which they were then elucidating; though in their care to get adequate necropsy proof, the work was not published till 1941 (B.H.J., 3, 37). The subjects discussed at each meeting and the speakers were recorded in Some Notes on the Cardiac Club by Cowan (1939).

$2 \mathrm{x}$ 
The affairs of the Club were managed by an executive-four members, of whom one retired each year and one was chosen as Secretary-and the Treasurer. The Chairman of each meeting was the senior member of the town where it was held, but he was not summoned to meetings of the executive until 1934. The first three secretaries were John Cowan (1922-25), A. G. Gibson (1925-28) and Crighton Bramwell (1928-32; Fig. 9). When Ritchie became an Extra-Ordinary member in 1932, the office of Treasurer was combined with that of Secretary, so that Evan Bedford (1932-36, Fig. 11) and Maurice Campbell (1936; Fig. 12) held the combined position and this continued to be the custom until 1958.

When the time came for the Club as such to come to an end, the Members all felt that its purposes had been achieved in good measure. They had attended regularly (every member was present in 1935); they had found the papers and discussions of help in their work; and they had formed many lasting friendships.

\section{The Start of The Cardiac Society (1937-39)}

The first recorded suggestion of changing the Club into a larger and less exclusive Society was made in June 1935. Although the Club had a very informal atmosphere, the customs at the dinner were more rigid: the health of the Chairman was proposed, generally by Wardrop Griffith or John Hay, the Chairman replying briefly, and no one else spoke. At the 1935 dinner, however, Fraser stood up and proposed the health of the secretary and made this the occasion to urge that a larger Society should be formed. The Executive (Allan, Drury, Bedford, and Wilkinson) were instructed to report on this to the next meeting. They discussed three possible plans: (1) the expansion of the Cardiac Club as such, without much other change: (2) the formation of a new Society independent of the Club; and (3) the plan they finally chose, the transformation of the Club into a much larger Society with a new constitution and rules. They circulated a well-argued memorandum and mentioned also the possibility of starting a journal devoted to cardiology: events have proved that they were right.

Their recommendations were discussed at length at Manchester in 1936, both on the evening before, for nearly all members then stayed at the same hotel, and at the end of the scientific meeting the next day. It would, I think, be fair to say that nearly all the members feared that the friendly and informal discussions would be jeopardized in a larger society, but agreed that in the interests of themselves and the many others who practised cardiology it was essential. They decided that the membership of the Club should be increased substantially, making provision for associate members, and that it should become a Society. A committee, consisting of Bramwell (chairman), Parkinson, Fraser, Bedford, and Campbell (secretary), was appointed to draw up a scheme and rules for such a society which were to be submitted to a special meeting.

This was held on January 8, 1937 in the Governor's committee room at Guy's Hospital, a fine room that was destroyed by incendiary bombs four years later. Sixteen members attended with Bramwell as chairman and approved the suggested rules with a few modifications. This seems to have been the moment when the Cardiac Club came to an end and the Cardiac Society was born. Many possible names had been considered-the Society of Cardiologists, the Heart Society, the Society for the Study of Cardiovascular Disease, but the final decision was for the Cardiac Society of Great Britain and Ireland. This was changed to the British Cardiac Society in 1946.

Three Honorary Members-Sir Arthur Keith, F. J. Poynton, and Graham Steele-were elected. The 7 Extra-Ordinary Members of the Club were given the same position in the Society. The other 6 original members, the 19 who had been elected to the Club later, and 19 others composed the 44 Ordinary Members, and there were 17 Associate Members. The new Council, representing the executive of the Club and the committee that had drawn up the new rules, was as follows: Allan (Glasgow), Bedford (London), Bramwell (Manchester), Parkinson (London), and Wilkinson (Birmingham), with the Secretary (Campbell) and Chairman-elect (Gilchrist). The most important features of the new Society were as follows.

The Society shall consist of up to 60 Ordinary, up to 25 Associate, and up to 20 Extra-Ordinary Members (making a maximum of 105), and of Honorary Members (Rules 6, 8, 10, and 14). The Chairman of each meeting shall be appointed by the Council; the Chairman-elect shall ex-officio become an additional member of the Council (Rule 16). The business of the Society shall be conducted by the Council. It shall consist of 
eight* Ordinary Members and in addition the Chairman-Elect, the Editors of the Journal* and the Secretary. Two of the eight* shall retire annually and shall not be eligible for re-election for one year. The Society shall elect two members to serve in their place and the Council may submit names for the vacancies. ( ${ }^{*} \mathrm{I}$ am quoting the rule as amended in 1938: in 1937 it read "five ordinary members, one of whom shall retire ..." and there was no editor of the journal.) (Rule 20.) The Council shall nominate an Ordinary Member for election as Secretary: he shall hold office for not more than five years and shall ex officio be a member of the Council (Rule 23):

The first annual meeting of the new Cardiac Society was held in Edinburgh on April 15, 1937 with Rae Gilchrist as Chairman. After approving the decisions of the special meeting and appointing a committee to consider the possibility of starting a journal (see p. 689), the morning was devoted to a discussion on high blood pressure. This was opened by Hay (Fig. 7), followed by Verney on experimental work, Parkinson (Fig. 8) and Bedford (Fig. 11) on its radiology, and Bramwell (Fig. 9)

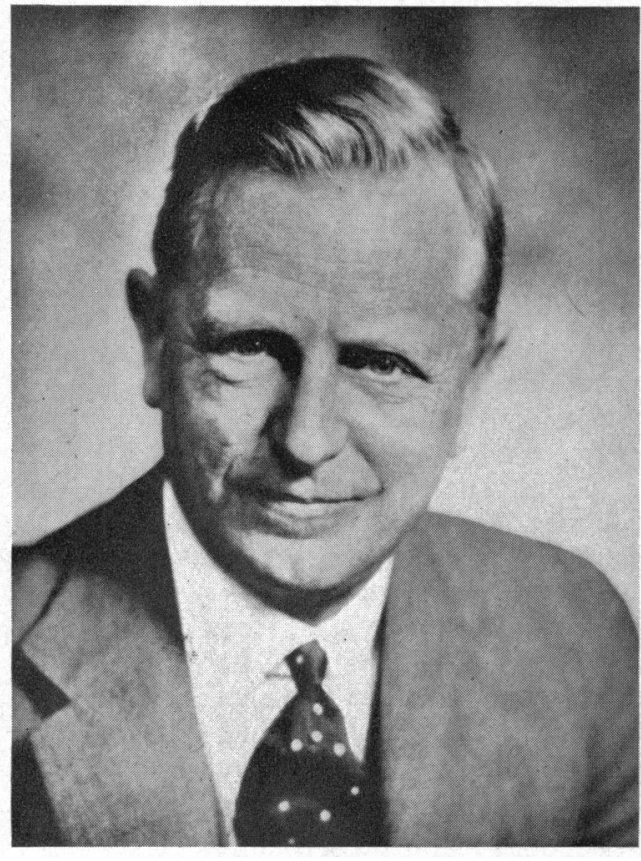

FIG. 7.- John Hay, an original member of the Cardiac Club, who was still an active member of the Cardiac Society.

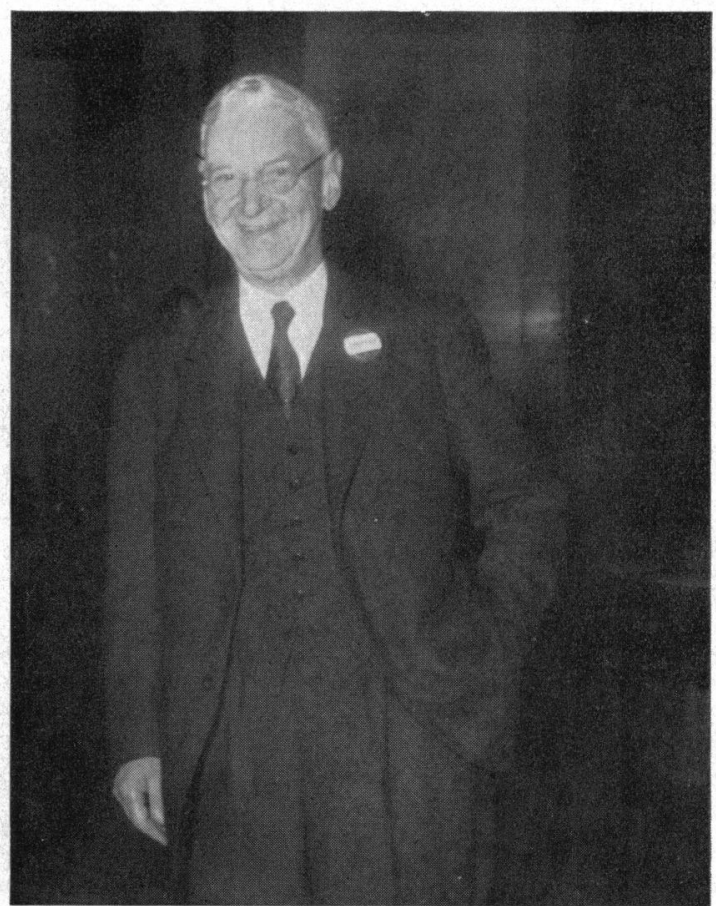

FIG. 8.-John Parkinson in 1936, an original member of the Cardiac Club and the first President of the Cardiac Society (1952-1956).

on its electrocardiography. In the afternoon, Arnott gave a demonstration on experimental hypertension and McMichael one on the circulation rate in heart failure, and these were followed by several short papers. I remember well the impression that Arnott and McMichael made on the meetingonly to be compared with the first occasion when Donald Hunter spoke to the Association of Physicians.

The day finished with a splendid dinner at the Royal College of Physicians, and its seven courses did not prevent us enjoying the beautiful and historic rooms in which we met. Probably there were some speeches but none were recorded on the printed menu. The intention was that all members of the Society were still members of the Club and that this was a club dinner without formal speeches. Even if there have been speeches at most dinners since, the spirit of this laudable intention has been preserved. 
The second meeting (1938) was held at Bristol with Herapath in the chair. The progress of the journal and lead IV committees was reported and steps taken about the journal were approved. The Council was made rather larger (see p. 683) and, noting that the rules did not distinguish between men and women, proposed Janet Aitken and Doris Baker as members. The morning was devoted to discussions on juvenile rheumatism, opened by Marshall and Wilkinson, and on coronary thrombosis, opened by Cassidy, Bedford, Parkinson, and Hall. In the afternoon there were 12 short communications, two on chest leads and one by Brenner on the pulmonary circulation. After dinner Sir Thomas Lewis spoke, wishing success to the Society and its new journal.

The third meeting (1939) was held at Birmingham, with Wilkinson in the chair. Four fifths of the members present voted in favour of an additional autumn meeting, but this did not materialize for ten years because of the war. As a sign of the change in money values it may be of interest that the members voted in favour of a dinner costing about 20/- with wine and tips included. There was no set subject for discussion as members had been asked to bring forward their new work. Among the 17 short papers, Barclay showed a film about changes in the fotal circulation. Dinner was held in the lovely old mansion, once the home of William Withering, and a good copy of his portrait by Von Breda looked down on us during dinner.

Up to this time, the programme of each meeting had been printed-a custom that had to be stopped during the war and has not been resumed. This seems the appropriate place to refer to some other activities of the Society during its first three very active years.

\section{Committees on Chest Leads and on Blood Pressure}

Apart from the meetings and the journal, the Society has from time to time appointed committees to report on various subjects. Two early ones were of special interest, partly because of their successful co-operation with the United States. In 1937 a committee to consider a standard position for taking a præcordial lead (Bedford, Cowan, Drury, Hill, Parkinson, and Wood) and a similar committee appointed by the American Heart Association (Barnes, Pardee, White, Wilson, and Wolferth) reached agreement and published their recommendations (Brit. Med.J. and Lancet, January 22, 1938, and in America; B.H.J., 1939, 1, 45). The British committee did not venture to recommend more than a single præcordial lead but the American committee included multiple præcordial leads. Ten years later, the report by another committee (East (chairman), Hill, Bain, and Wood) decided in favour of $\mathrm{V}$ leads rather than CR or CF leads, though some advantages of CR leads were (and still are) pointed out (B.H.J., 1949, 11, 92 and 103).

In September 1938 the American Heart Association had set up a committee to standardize methods of taking arterial blood pressure (Barker, Erlanger, Meakins, Schneider, Scholz, Ungerleider, White, Wiggers, and Wright) and the Cardiac Society, when asked if they also would do so, appointed Bramwell, Campbell, Cotton, William Evans, Gilchrist, and Hay. It may seem to some that this was not needed but most members were surprised that the methods they used were not exactly the same as those used by everyone else. It was something of a triumph that the two committees reached agreement on a text that could be published over the joint signatures of them both in 1939 (Brit. Med. J., 2, 184, and B.H.J., 1, 261, and in America): it has proved useful by helping to bring into use agreed standards that are specially important for life assurance examinations.

\section{Subsequent Progress of the Cardiac Society (1940-1961)}

The activities of the Society, like so many other things, were disturbed by the war but meetings were arranged each year. From 1940-47 they were held in London, except when we went to Cambridge in 1942 and to Oxford in 1941 and 1946. At the 1941 meeting at Merton (Fig. 9), Gibson showed the College books and records connected with William Harvey who had been Warden of the College during the Civil War. Since 1941, the Proceedings of the Society have been printed in the Journal-a wise decision that has helped to emphasize its close connection with the Society. Campbell had now completed his five years as secretary but by annual resolution, he was re-appointed for another five years to preserve some continuity during the war.

After 1942 when the Council invited Commonwealth and American cardiologists serving in 


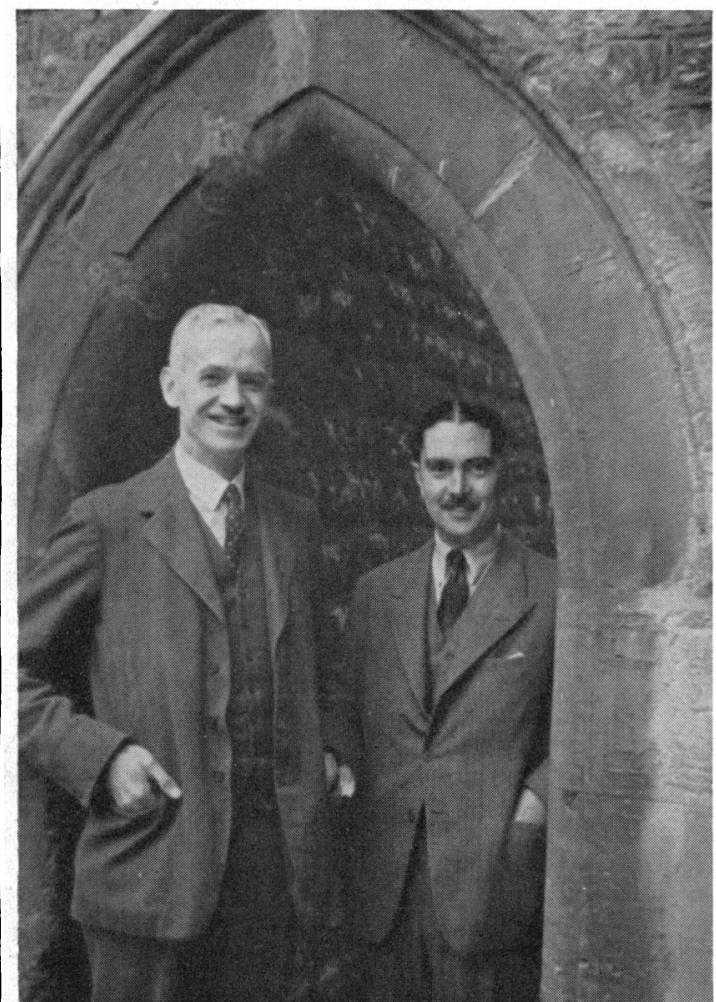

Fig. 9.-Crighton Bramwell, the third secretary of the Cardiac Club, with Swan, at Merton College, Oxford, in 1941.

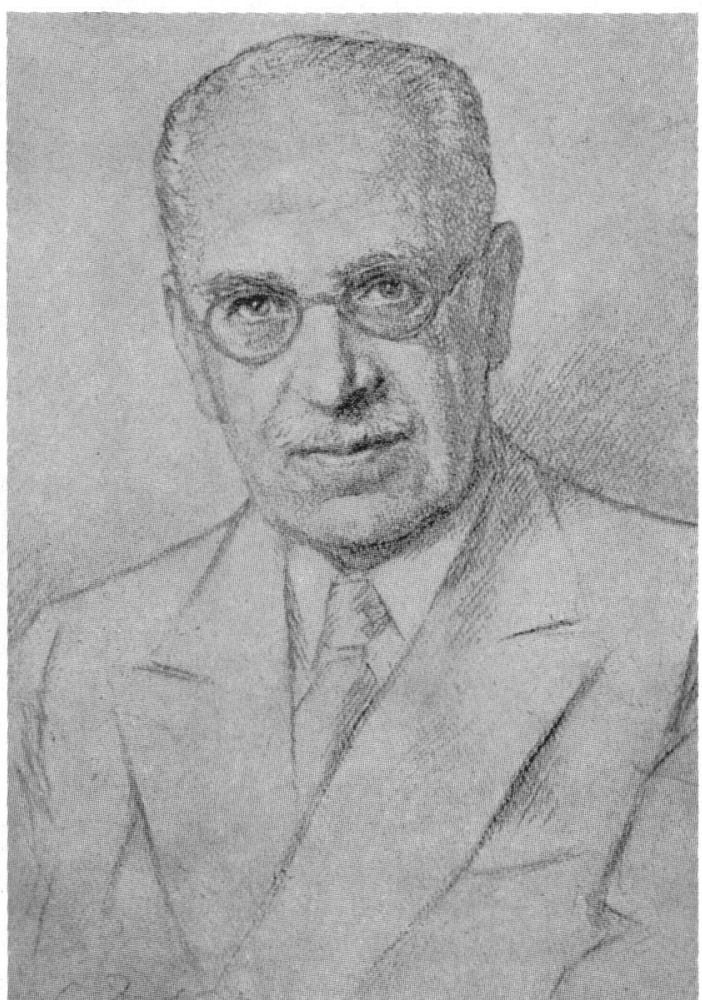

FIG. 10.-Maurice Cassidy, chairman 1935 and 1943, from a chalk drawing by Mrs. Campbell Dodgson.

Europe to attend the meetings, between 40 and 50 members and 20 others were generally present. Apart from the usual short communications which included papers on closure of a persistent ductus by Bourne in 1942 and by Gilchrist in 1944, and on unexplained heart failure in the African by Bedford and Konstam in 1946, there were several discussions. Some of these were the early diagnosis of heart disease (1941), cardiac defects found at medical boards (1942), and cardiology in a co-ordinated medical service (1943) for the National Health Service was being discussed, and on the treatment of bacterial endocarditis with penicillin in 1946.

The Society made representations to the Ministry of National Service on the medical examination of recruits and in 1943 was asked to advise on the rehabilitation of cardiac patients. The report of this committee-Cassidy (chairman), Evans, and Campbell (secretary) -was approved by the Council (B.H.J., 1944, 6, 249). Both the British Pædiatric Association and the Cardiac Society had appointed committees to report on the care of rheumatic children (Parkinson and Bruce Perry with the same chairman and secretary) and agreement was reached after a joint meeting (B.H.J., 1944, 6, 99).

Only the 1944 meeting had to be abandoned when the Government discouraged any gatherings in London. In 1946 the Society asked the Royal College of Physicians if it would appoint a Committee of Cardiology. The report of this Committee under the chairmanship of Cassidy (Fig. 10), published in April 1947, dealt with the training of specialists in cardiology, the practice and teaching of cardiology, and the planning of cardiac services under the National Health Scheme. A reconstituted committee, with Campbell as chairman, met several times in 1957-58 and tried to implement 


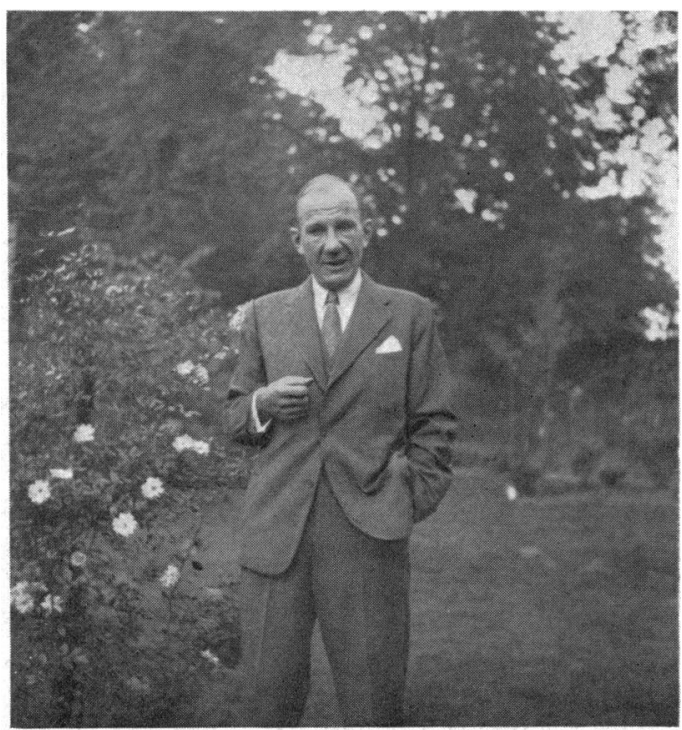

FIG. 11.-Evan Bedford, the fourth secretary, in Parkinson's garden at Hampstead.

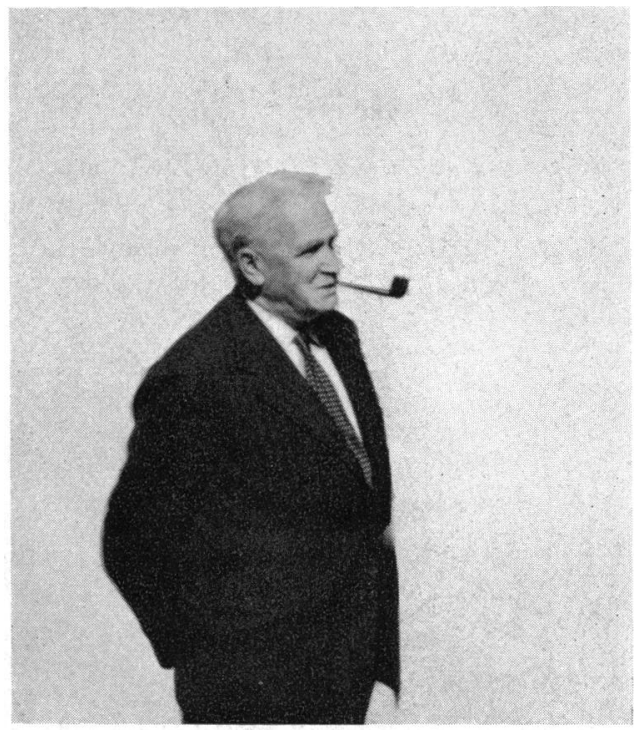

FIG. 12.-Maurice Campbell, the fifth secretary, at Boston in 1954.

this report further and to increase the number of cardiologists in the country: its report was approved by the College and published in October 1958.

In spite of the war, the Society was nearly as large as the rules allowed by 1946. The Council recommended that there might be up to 145 (instead of 105) members; that the name should be changed to the British Cardiac Society; and that Corresponding Members might be elected from the British Commonwealth and abroad: all these changes were accepted. Shirley Smith was appointed secretary for 1946-51, to follow Campbell.

In 1947, the main discussion was on cardiac emergencies, and Evans gave a paper on familial cardiomegaly. From September 9th-12th in that year the International Conference of Physicians was held in London-a courageous decision of Lord Moran for conditions were still difficultand there was a section of Cardiology with Sir Maurice Cassidy as President: Shirley Smith was secretary and developed the skill that was found so valuable when the European Society met in London five years later. Dr. Helen Taussig and Dr. Blalock spoke about their operation for Fallot's tetralogy, Mr. Crafoord about that for coarctation, and Holmes Sellors, Tubbs, Gilchrist, and others spoke about that for persistent ductus. A discussion on pulmonary heart failure was opened by McMichael, Lenègre, Brooks, and Wood; one on chest leads by Frank Wilson, Bain, East, and Hill; one on phonocardiography by Evans, Lian, and Minot; and there were many shorter papers (B.H.J., 1948, 10, 65).

Thereafter, the usual round of meetings outside London was resumed. In 1948 at Liverpool, with 82 members present, the main discussion was about sympathectomy for hypertension and there were other papers on chest leads, on phonocardiography, and on angiocardiography. The rules were changed so that surgeons interested in the heart could be members and six were elected.

Since 1948, additional autumn meetings have been held except when there has been an international meeting. At the first one, the second report on chest leads was accepted (see p. 684). Leatham gave a valuable paper comparing CR, CF, and V leads (B.H.J., 1950, 12, 213); Campbell and Hills, one on angiocardiography in congenital heart disease (B.H.J., 1950, 12, 65); and there were two papers on phonocardiography.

A large and successful joint meeting with the Thoracic Society was held at the Westminster 
Hospital on February 25, 1949, to discuss the progress that was being made with congenital heart disease. Brown and Campbell each spoke of their experience, the latter emphasizing the frequency of pulmonary stenosis with a closed ventricular septum. Frances Gardner and Brigden discussed angiocardiography, Wood and Sharpey-Schafer the technique and difficulties of cardiac catheterization, and Brown and Allanby the embryology and pathological anatomy of simple pulmonary stenosis: during the meeting there was an excellent exhibition of congenital heart disease provided mainly by these two speakers. Brock described his experience with anastomotic operations and with direct operations for pulmonary stenosis, which had been carried out successfully since February 1948.

The 1949 meeting, with Boyd Campbell of Belfast as chairman, departed from precedent in being the only occasion when wives were invited and when the meeting took place away from the sponsoring medical school, at Newcastle, Co. Down, where the mountains of Mourne come down to the sea. The discussions on the ætiology of acute rheumatism and on rheumatic heart disease in pregnancy had been well arranged beforehand by the four opening speakers who were all from Belfast. Leatham spoke on the phonocardiogram of aortic stenosis and four of the other eight communications were on congenital heart disease.

At the 1950 meeting, at the Westminster Hospital with Stott as chairman, more than 100 members were present for the first time. The discussion on anticoagulants was opened by Gilchrist, Learmonth, Macfarlane, and Shirley Smith, and there were also several short papers on this subject, and one on œsophageal leads by Bain. In the autumn, the first World Congress of Cardiology was held in Paris (see later).

At the 1951 meeting at Glasgow, with Wright as chairman, Samuel Oram was elected secretary for 1951-56 to follow Shirley Smith. The main discussion was on heart disorders of pulmonary origin, opened by McMichael, Thomas, Wood, and Florence McKeown: there were two papers on vectocardiography and a colour film of movement of the heart valves was shown by McMillan and Daley. At the autumn meeting, there were 3 papers on coronary disease, 2 on persistent ductus, and 4 on various aspects of mitral stenosis.

I am giving less space to the meetings of the next decade because they are familiar to more members and will be seen in better perspective at some later time. In 1952, the whole time was given to the 15 short communications. The rules of the society were changed and its maximum numbers were increased (see p. 692). Mainly because of the international meetings, the society decided that it should have a President. Naturally, Sir John Parkinson was elected, for he had been the main inspiration of the Society in its early days, and the October 1951 number of the journal had been dedicated to him as a token of the admiration and affection that the Society felt for him. He was re-elected as President for four years. It was laid down that the president should not take the chair at the annual meetings for which a chairman was to be appointed as before.

In 1953, after the European Congress in London, 33 Corresponding Members were elected, and the society has been pleased to see some of them at its subsequent meetings. Both meetings were entirely devoted to short papers - 5 on congenital, 4 on coronary, and 9 on rheumatic (mainly mitral stenotic) heart disease, and 11 on other subjects. In 1954, the short papers included one by Ball and Davies on endomyocardial fibrosis (B.H.J., 17, 337).

In 1955, both meetings were again devoted to short papers and the subjects were unusually varied. In 1956, Campbell succeeded Parkinson as President, and it became the custom for the President to preside at Council meetings and for Private Business at the general meeting before handing over to the Chairman for the rest of the meeting and the dinner. Patrick Mounsey succeeded Oram as Secretary and Treasurer for 1956-61, but by 1958 the work had increased so much that these offices were divided and John Goodwin was appointed Treasurer.

In 1957, there was a special subject for discussion, in which Samuel Levine of Boston had been invited to take part. He spoke of some puzzling points about coronary heart disease and Oliver and Boyd spoke about its atiology. Professor Walmsley demonstrated some of the anatomical relationships of the heart (B.H.J., 1958, 20, 441). 
In June 1957, a special meeting of the Society was held during the Harvey Tercentenary Congress and several papers were read by our members. Campbell, Brock, d'Allaines, and Brom, with Price Thomas as chairman, spoke about the results of cardiac surgery and afterwards discussed their conclusions with their colleagues in America on the trans-Atlantic telephone. The autumn meeting was devoted to short communications and two exceptionally good colour films. William Harvey and the circulation of the blood was based on the earlier film made by Lewis and Dale in 1928 and remade in colour by the film unit of the Wellcome Foundation under the direction of Sir Henry Dale. The jugular venous pulse, a film produced by Paul Wood, showed how much can be learned from a careful study of this pulse. The three meetings of this year showed the amount of work that was now available.

In 1958, the Society held a two-day meeting at Leeds with Towers as chairman (Fig. 13). Even so, many papers had to be taken as demonstrations-a custom that has continued. There were also

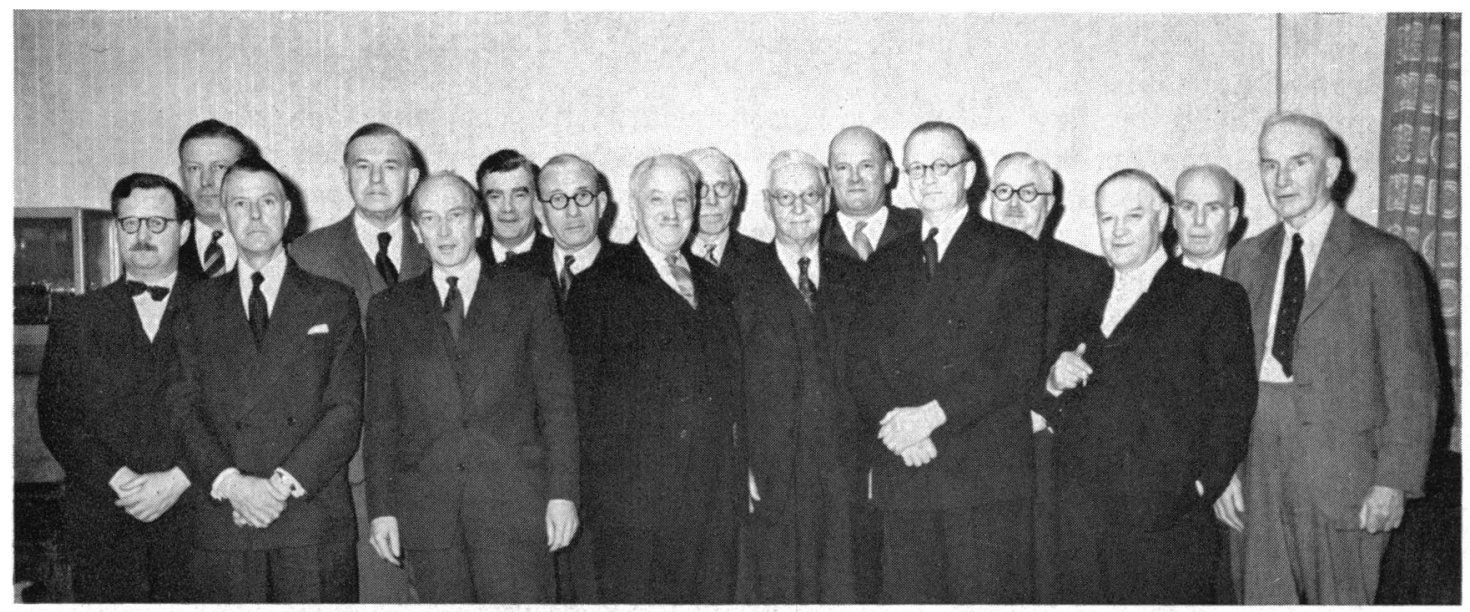

FIG. 13.-Some senior members of the Cardiac Society at the 1958 meeting at Leeds. Back row: Hayward, Bourne, Morgan Jones, Bedford, Peel, Gilchrist, William Evans, and Phillips. Front row: Whittaker, Shirley Smith, Wood, Campbell, Parkinson, Towers (chairman, 1958-59), Wright, and Boyd Campbell.

discussions on the extra-corporeal circulation and on diuretics, but since then all the available time has been occupied with short communications. It has been an invidious task mentioning individual papers, but they have been chosen to illustrate trends of interest rather than their own merits.

In 1960, Dr. Samuel Levine gave the Society a generous donation to found a lecture to commemorate the great influence of Sir Thomas Lewis on cardiology and the gratitude felt by himself and other American physicians for what they had learnt when working with him. With Levine's approval, Tom Cotton added to the capital, so associating Canada and Britain with the United States. The minutes record the gratitude of the Society for their generous gifts. In 1960, Evan Bedford followed Campbell as President and in 1961 John Shillingford was appointed Secretary for 1961-66 to follow Mounsey. For the last few years the recorded attendance, which is far from complete, has been between 152 and 180 members with about 35 visitors.

The Society has continued to be at least as successful as the Club. There are always more proposals for new membership than the Society can admit; a large proportion of the members attend the meetings; and more good papers are offered than there is time for, and these have been well prepared, with excellent slides. The members have developed and maintained a high standard of clarity without reading their papers (which is forbidden) and keep to their allotted times so that papers by others and discussions are not unduly cramped. Naturally a much smaller proportion of members speak in 
the discussions but the friendly informal atmosphere remains: there can be no doubt that more work of a much higher scientific standard has been reported to the Society.

\section{WORLD AND EUROPEAN CONGRESSES}

On January 29, 1949 a meeting took place at Brussels, under the ægis of la Société Belge de Cardiologie, between delegates of fourteen European countries to constitute a European Cardiological Society. Evan Bedford represented the British Cardiac Society. Bye laws were drawn up and Van Dooren (Belgium) was appointed Secretary and Mahaim (Switzerland) Treasurer. They hoped that the new Society in conjunction with the Pan-American Cardiological Society would form the International Cardiological Society (B.H.J., 1949, 11, 296).

The First World Congress of Cardiology was held in Paris in September 1950 under the chairmanship of Professor Charles Laubry. It was a memorable occasion with many valuable communications. The beautiful halls in which we met, the friendly lunches in so many Paris restaurants, and the magnificent banquet will still be remembered by those who were present.

From September 9-12, 1952 the First European Congress of Cardiology was held in London. At its 1951 meeting the Cardiac Society had appointed a committee-Bedford (Chairman), Bramwell, Campbell, Oram, Parkinson, Wood, and Shirley Smith, to whom the Society are indebted for his splendid work as Secretary of the Congress. The opening addresses of Sir John Parkinson, Professor Charles Laubry, and Professor Nylin were published (B.H.J., 1953, 15, 1). Nylin paid a handsome tribute to the work on the heart and circulation by British physicians and physiologists from Harvey to Starling, who in his Linacre lecture nearly three hundred years later gave the first detailed study of the diastolic filling of the heart, and to modern times.

One morning was devoted to a discussion of the surgical treatment of mitral stenosis with Campbell, Soulié, Werkö, Froment, and Wood as opening speakers and as the whole of another session was devoted to papers on this, it was the main subject of the congress, even more than congenital heart disease. The 91 papers chosen to be read were listed in this journal $(14,547$ : see also Lancet, 1952, 2, 575 and Brit. Med. J., 2, 657). No full proceedings were published as they have been for most of our congresses: the work and expense involved are of doubtful value in my opinion, for such Proceedings may be hard to obtain in many libraries, and the papers are often published elsewhere in their final form.

Since then, European Congresses have been held in Stockholm under Professor Nylin (1956) and in Rome under Professor Condorelli (1960), and World Congresses in Washington under Dr. Paul White (1954) and in Brussels under Professor Rijlant (1958): the fourth is due to be held in Mexico in October 1962 under Professor Chávez.

They have been attended by increasing numbers of cardiologists from more and more countries. All have been distinguished by addresses, papers, discussions, and demonstrations of scientific value and all have provided a happy and enjoyable meeting ground. Each congress has been marked by some outstandingly successful features, but none has quite solved the difficult problem of making a meeting with so many members and so many communications run with the smoothness that we have learnt to expect in our smaller national societies. Perhaps this perfection is impossible with the larger numbers, but Professor Ignacio Chávez may show us in Mexico how it can be attained.

\section{British Heart Journal}

One early venture that was closely linked with the Cardiac Society was the start of the British Heart Journal. At the first Meeting of the Society in April 1937, a committee, consisting of Gibson (chairman), Bedford, Campbell, Fraser, and Wilkinson, was appointed to consider starting a journal dealing with cardiology. Since Heart had changed its subject matter and become Clinical Science in 1933, the need for such a journal had been felt but its start was thought too difficult without the support of a larger society. The Committee held several meetings during the summer and autumn. 
Many titles for the journal were considered. Wilkinson suggested De Motu Cordis, but this was felt too irreverent. I favoured Heart to follow the great traditions that had been started by Brain and enhanced by Heart: at first Lewis demurred though finally he agreed subject to the permission of the publishers, but this was not forthcoming. The title selected was suggested at an early stage, though the arguments against the use of heart as an adjective were fully appreciated. Campbell was chosen to be editor and insisted on having Bedford as a colleague, particularly because of the latter's greater knowledge of radiology. After meetings with the Special Journals Committee of the British Medical Association and with Hugh Clegg, the editor of their journal, it was decided that the B.M.A. should be asked to publish it, as they seemed able and willing to produce a journal that would meet the needs of the Society.

In contrast with the democratic constitution of the Cardiac Society, the editor of the Journal was placed in an autocratic position, as can be seen from the decisions that follow. The Editor or Editors shall be appointed by the Council for five years, and shall be eligible for reappointment. They shall be in general control of the Journal and shall refer such matters as they think fit to the Editorial Board. They shall call a meeting of the Board when necessary. The Editorial Board shall consist of not less than six and not more than twelve members, due regard being paid to territorial representation. They shall be appointed by the Council after consultation with the Editors. They shall advise on general policy and shall make their recommendations about the appointment of Editors to the Council.

The Editor must be all-powerful in the day-to-day work of the journal, but there has, in fact, never been any disagreement with the Editorial Board whose help and advice have been of much value. It seems clear that in the case of serious disagreement, the Council of the Cardiac Society has the final say and can force the resignation of the Editor or Editorial Board or both.

By November 1937, most of the necessary decisions had been reported to the Council, which in February 1938 appointed the editors and editorial board. Their action was approved by the Society in June and the first number of the British Heart Journal was published in January 1939.

Some of us felt that it was unenterprising that the Cardiac Society should not own and publish the Journal itself. The arrangements made have, however, proved admirable and the difficulties of printing and of paper rationing during the war would probably have brought the Journal to an untimely end, even if the Society had managed to find someone competent to arrange contracts with the printers and to do the necessary business, all of which duties were carried out in the best interests of the Journal by the British Medical Association.

Before the last number of the first volume had appeared, the war had started. After the work already completed had been written up and published in 1940, the journal became smaller and was no more than $182 \mathrm{pp}$. in 1942: it did not regain the size of the first volume for nearly ten years. The numbers appeared regularly, even that of April 1941 though the works of the printers had been severely damaged in an air raid shortly before. After the war, publishing became more difficult, and the journal had to be printed on paper of very inferior quality with smaller margins in 1946-49 and in double column and smaller type in 1948-49. I had forgotten it was so long after the war that the difficulties and delay became most acute.

The editor of the British Medical Journal and his Special Journals Committee were always most helpful: indeed, they have been generous to our journal and meticulous in carrying out their agreement that the control of policy was entirely in the hands of the Cardiac Society and its editors. In 1951-52 after the steep rise in the cost of printing and paper, they had to insist on a smaller journal for a time, but they have never complained about the number of illustrations, though perhaps the editors have helped by limiting their contributors to a reasonable number. The relations with the printers, Messrs. William Clowes \& Sons, have been equally happy, and the name of $\mathrm{Mr}$. Coupland, a senior member of their staff who taught the editors so much and so tactfully in the first eight years, should be remembered. Readers may like to know that the journal is printed at Beccles in Suffolk, though the blocks are made in London.

The Editorial Board did not meet until 1947, though its members always helped the editors 
when questions were referred to them. Since then it has met most years and has helped to lay down a consistent policy for accepting papers. Reading through the minutes of their meetings it seems that, though the journal has grown, most of their time has been spent on trying to keep it within reasonable limits. This struggle has had advantages for it has forced the editors to strive for more brevity even in well written papers and for less prolixity in others. It is easier to accept a paper as it is than to return it explaining how is should be shortened; but the time that has been spent on this aspect has been rewarded by shorter and more readable papers.

From an early stage the journal was meant to bridge the barriers separating existing divisions in medical science. By providing common ground on which physicians, anatomists, physiologists, and pathologists could meet and pool their efforts, it should enable those who treat the sick and those who work mainly in the laboratory to keep in touch with each other's problems to their mutual advantage. These hopes have, I think, been fulfilled, and excellent papers on physiology, anatomy, and pathology have been published, though perhaps not so many as was hoped. The editors of a journal connected with a society have the advantage of learning the subjects in which the members are interested and can make sure that most of the best papers given at these meetings will be available for the journal; and there can be no doubt that good papers attract others.

Since 1951, reports of single cases have been accepted only as Case Reports. These must include a necropsy or physiological investigations of special interest, and should not occupy more than three pages of the journal, including the one or two illustrations. From 1947 to 1959 , a few pages in most numbers were devoted to abstracts of world cardiological papers with the help of Abstracts of World Medicine.

In 1956 it was decided to publish a cumulative index for the journal. This had been envisaged after about 20 years (1959) but the opportunity of having the help of one of our members, Sheila Howarth, made it worth doing at once for the years 1939-55, and this was published as a separate number in 1957. It is hoped that this may be repeated not later than 1967.

Naturally the first volumes consisted mainly of papers written by members of the Cardiac Society but even in the first two years there were papers from Australia, Egypt, India, and the United States. By the end of the war they had come also from New Zealand and South Africa, from Sweden and Turkey, and from Israel and Venezuela. Now papers have been accepted from every country in Europe on this side of the iron curtain, from Hungary and Czechoslovakia, and from other parts of the world.

The following figures showing the country of origin of the papers published have been taken from the reports to the Editorial Board. All the groups outside Great Britain have increased their contributions and are now responsible for about one quarter of each number.

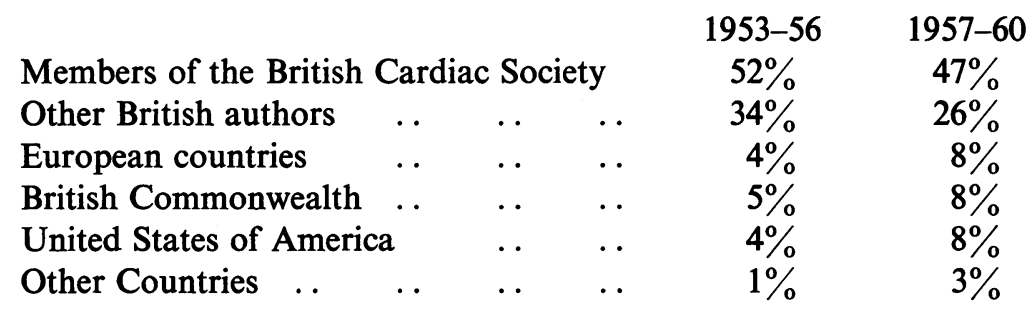

In the first ten years the average volume contained 267 pages, in the next five years 497 pages, and in the last five 570 pages. The quality has improved at the same time, not only in style of writing and brevity of expression, but in the physiological and experimental work that is so often reported as well as more purely clinical papers. Fortunately the circulation has increased much more than the size of the journal.

Editors. At the start Campbell and Bedford were appointed editors. Bedford did his full share of the first volume but joined the army soon after the war started and spent some years in the Middle 
East: though he helped again after his return, he retired in 1948. Shirley Smith was appointed associate editor in October 1948 and Terence East was added in November 1950 and helped greatly for four years. When he retired in January 1954, three assistant editors-Hill, Hayward, and Brigden - were appointed. They served for four years and in 1957, Mounsey was added.

At the end of 1958, Campbell had completed 20 years and felt that it was time to hand over the editorship: he offered to become one of the assistant editors but the Board decided that consulting editor was more appropriate. Shirley Smith became editor and Goodwin assistant editor. Mounsey retired at the end of 1960 and Somerville was appointed in his place; and in 1961, as the work and the size of the journal were still increasing, Short and Jackson and McDonald were added as assistant editors.

Except for the first three editors, none have felt able to give the time for more than four or five years: as it takes a year or two before they can take on much of the work, this is obviously undesirable. To try and avoid this recurring difficulty, plans have been made for more help from the editorial staff of the B.M.A. so that the editors chosen may continue their work for longer periods.

Throughout the years the editors have tried to remember that they are the servants of the Society and to accept papers that will be of interest to the members. This principle has certainly made it easier to know what to select and what to refuse and has, I think, helped in the success of the journal.

\section{THE GROWTH OF THE SOCIETY AND THE FutURE}

Throughout the $\mathbf{4 0}$ years, the Society has continued to grow and generally at an increasingly rapid rate. Indeed this has been, and is still, one of the main problems for the Council. In the first stage (1922-37) the Cardiac Club grew slowly from 15 to 32 members in 15 years-not much more than one a year. The expansion to the Society doubled it suddenly, to 68 members. It was thought then the maximum numbers allowed -60 ordinary, 25 associate, and 20 extra-ordinary members; 105 in all-would be large enough for a long time.

In the second period (1937-51) the rate of growth was faster and it was only because of the war that ten years passed before the Society was.full. The Council thought that 1946 was not a time for real reconstruction and, as a temporary measure, increased the maximum allowed to 145 . The pressure to join the Society was emphasized by the formation soon after the war of the Junior Cardiac Club of London (Fig. 14) which meets several times a year: except for the members who have returned to the Commonwealth, most of the others have later become members of the Society. The average number of new members of the Society increased from 3 a year to 6 a year, so that by 1951 it was again full and the Council appointed a committee, consisting of Parkinson, Bedford, Campbell (chairman), Shirley Smith, and Oram (secretary), to consider the future numbers and any other changes in the rules. The committee tried to obtain the views of all members by circular and to decide an ideal maximum number, from two points of view-the numbers of suitable candidates and of centres large enough for comfortable meetings. When in 1952 the rules were changed to allow 250 members-225 ordinary and associate members so that there would be no undue delay in associate becoming ordinary members and 25 extra-ordinary members-it was hoped that a position had been reached that would last.

In the third stage (1952-61), however, the rate of growth became much faster. In 1956 I submitted a memorandum to the Council, setting out these facts and that in five years 70 new members (14 a year) had been elected and that if this continued no new members could be elected after 1959 . The Council became even more selective in its choice of new members and has elected an average of 10 a year (in 1957-61): allowing for the 3 a year who were made extra-ordinary members (their maximum number was increased from 25 to 40 in 1960), the average increase has been 7 instead of 14 new members for the last five years.

Even so, there are now only 23 vacancies and the Society could easily reach the maximum allowed in the next two years. The problem may already be under consideration by the Council and by the Society, and members should ask themselves how many others they know who should become 


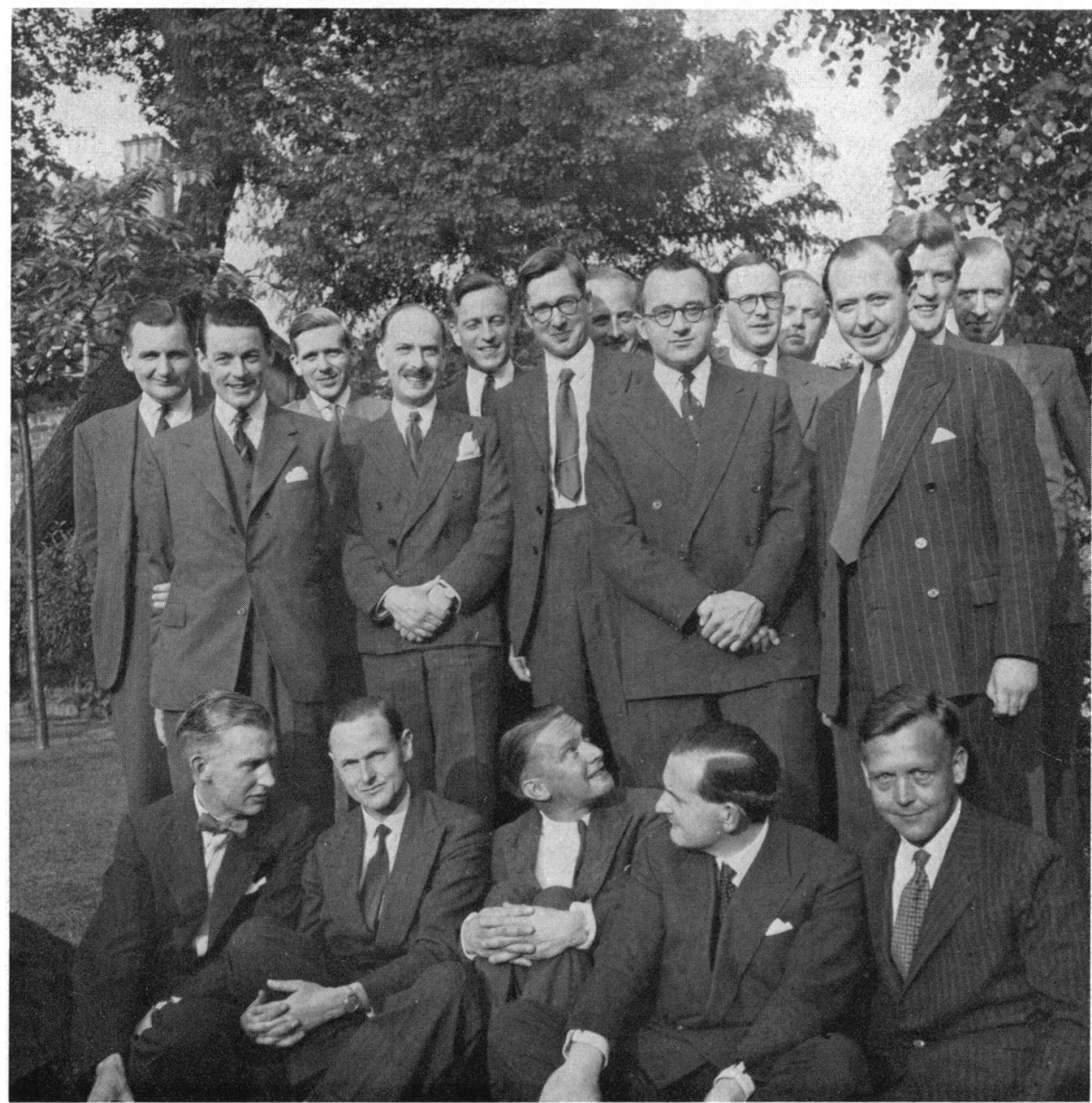

Fig. 14.- Some members of the Junior Cardiac Club, taken by John Parkinson in his garden in 1952. Mounsey and Shillingford, the last two secretaries of the Cardiac Society, and Goodwin, the treasurer, and others were then members of both societies.

Standing: Shillingford, Wilson, Goodwin, Mounsey, Lowe, Leatham, McDonald, Zoob, Baylis, Matthews, Daley, Pryor, Epps. Sitting: Somerville, Woods, Holling, Allanby, Wells.

members and 'when they wish this process of growth to stop, from the point of view of finding convenient meeting places and of having a balanced Society where it is possible for most of the members to know each other.

Whether the Society will end with 350 or 1000 members is not known, but I am sure the Council will decide wisely according to the circumstances of the time. I wonder if associate membership might not now be abolished. At the start the senior members feared that their traditions might be disturbed by the influx of new members, but this no longer applies and nearly all associate members become ordinary ones: younger men might be introduced as visitors till they were elected members. The Council has undergone only minor changes during the years. A larger council could represent more geographical areas but would hardly conduct the business so effectively. The Council has, I think, always succeeded in carrying out the wishes of the Society, and if it does not the Society can 
put forward any names it wishes and in two years could replace half the old council by its own nominees.

I have a letter from John Cowan expressing his regret for his biological error in finishing his Notes on the Cardiac Club with the words "Webb's egg has grown etc.," when he should have written "Webb's egg has hatched: the stripling is thriving." Even he would be surprised and pleased to see the size and vigour of the stripling today.

I am greatly indebted to John Parkinson and Evan Bedford for making useful additions and suggestions from their memories of the Cardiac Club; to Shirley Smith for the same help in the part about the British Heart Journal; to Robert Marshall, William Phillips, Ian Hill, J. H. Wright, John Towers, and Wyn Jones for help with individual memoirs; and to John Shillingford for help with the minutes of the British Cardiac Society. It is a pleasure to express my thanks to John Hay for giving me many of his photographs over the years, and to his son John Hay for allowing me to select some others from his collection, and to Parkinson for some more recent ones.

I would like to thank Mr. Rollo St. J. Charles, Keeper of Art at the National Museum of Wales for permission to reproduce the portrait of Sir Thomas Lewis by Evan Walters, and William Phillips for his help in arranging this: the original is on loan to the Welsh National School of Medicine from the National Museum of Wales.

\section{REFERENCES}

Campbell, M. Personal memories of all meetings from 1930 to 1962 (and 1927) except 1948 when he was in America. Coombs, Carey, F. (1924). Rheumatic Heart Disease. John Wright and Sons, Bristol.

Cowan, J. (1914). Diseases of the Heart. Edward Arnold, London (later editions with W. T. Ritchie).

, and others (1939). Some notes on the Cardiac Club. Brit. Heart J., 1, 97.

Gibson, A. G. (1933). The Physician's Art. Oxford at the Clarendon Press.

Mackenzie, James (1902). The Study of the Pulse. London.

Minute Book of the meetings of the Cardiac Club and of its executive, 1922-37.

Minute Book of the British Cardiac Society, 1937-61.

Minutes of the Council of the British Cardiac Society, 1952-60.

Patterson, S. W., and Starling, E. H. (1914a). On the mechanical factors which determine the output of the ventricles. J. Physiol., 48, 357.

, Pipe1, H , and Starling, E. H. (1914b). The regulation of the heart beat. J. Physiol., 48, 465.

Wilkinson, K. D., and Peck, T. W. (1950). William Withering of Birmingham. John Wright and Sons, Bristol.

\section{Memoirs of Original Members of the Cardiac Club}

Coombs, Carey F. (1879-1932). Brit. med. J., 2, 1126, and Bristol med-chir. U., 49, 326.

Cowan, John (1870-1948). Brit. Heart J., 10, 1.

Emanuel, J. G. (1871-1958). Brit. Heart J., 20, 579.

Gibson, A. G. (1875-1950). Brit. Heart J., 13, 255.

Griffith, Wardrop (1861-1947). Brit. Heart J., 9, 77.

Hay, John (1873-1959). Brit. Heart J., 21, 573.

Horder, Lord (1871-1955). Brit. Heart J., 18, 123.

Hume, Sir W. E. (1879-1960). Brit. Heart J., 22, 426.

Lewis, Sir Thomas (1881-1945). Brit. Heart J., 8, 1.

Macllwaine, J. E. (1874-1930). Lancet, 2, 428.

Mackenzie, Sir James (1853-1925). Heart 12, i-vii, 1925-26.

Ritchie, W. T. (1873-1945). Brit. Heart J., 7, 207.

Starling, H. J. (1873-1950). Brit. Heart J., 13, 2581

Wilkinson, K. D. (1886-1951). Brit. Heart J., 13, 556.

\section{Memoirs of Honorary Members of the British Cardiac Society}

Abbott, Maude (1869-1940). Brit. Heart J., 3, 139.

Gallavardin, Louis (1875-1957). Brit. Heart J., 20, 299.

Herrick, James B. (1861-1954). Arch. intern. Med., 41, 410.

Keith, Sir Arthur (1866-1955). Brit. Heart J., 17, 409.

Laubry, Charles (1872-1960). Brit. Heart J., 23, 215.

Nylin, Gustav (1892-1961). Brit. Heart J., 23, 721.

Poynton, F. J. (1868-1943). Brit. Heart J., 6, 96.

Steele, Graham (1851-1942). Brit. Heart J., 4, 115.

Wenckenbach, Karel (1864-1940). Brit. Heart J., 3, 141.

Wilson, Frank (1890-1952). Brit. Heart J., 15, 259. 
Memoirs of other Members of the Club and of the Society

Abrahamson, Leonard (1897-1961). Brit. med. J., 2, 1295.

Allan, George, A. (1876-1950). Glasgow med. J., 31, 422.

Allison, D. R. (1902-1953). Brit. med. J., 2, 1382.

Brown, James (1897-1958). Brit. Heart J., 21, 284.

Cassidy, Sir Maurice (1879-1951). Brit. Heart J., 13, 253.

Gill, A. Wilson (1888-1948). Brit. med. J., 2, 578.

Gosse, Hope (1882-1956). Brit. Heart J., 18, 563.

Hall, Donald G. (1877-1949). Brit. med. J., 1, 729.

Herapath, C. E. K. (1882-1947). Brit. Heart J., 9, 80.

Hobson, F. G. (1891-1961). Brit. Heart J., 23, 716.

Hoskin, Jenner (1888-1954). Brit. Heart J., 16, 325.

Jones, H. Wallace (1888-1958). Brit. med. J., 2, 1045.

Kennedy, A. M. (1885-1960). Lancet, 2, 820.

Konstam, Geoffrey (1899-1962). Brit. Heart J., 24, 517.

Levick, C. Blaxland (1896-1953). Brit. med. J., 1, 1336.

Lovibond, J. L. (1907-1954). Brit. Heart J., 16, 465.

Moore, Henry (1887-1954). Brit. med. J., 1, 337.

Parsons-Smith, B. T. (1882-1954). Brit. Heart J., 17, 263.

Patterson, S. W. (1886-1960). Brit. med. J., 1, 1575.

Poulton, E. P. (1883-1939). Guy's Hosp. Rep., 89, 251.

Rook, Air Vice-Marshall, Sir A. F. (1892-1960). Lancet, 2, 605.

Snodgrass, W. R. (1890-1955). Lancet, 2, 1199

Stott, Sir Arnold (1886-1958). Brit. Heart J., 21, 137.

Wood, Paul H. (1907-1962). Brit. Heart J., 24, 661, 